\title{
Estimation of Concentration of Naturally Occurring Radioactivity and Radiation Hazards, in Iron Ore Deposit Soil from Wag-Himra Zone, Ethiopia
}

\author{
Tadesse Gebeyehu*, Baye Zinabe*, Teshager Akalie \\ Department of Physics, College of Natural Science, Mekdela Amba University, Mekdela Amba, Ethiopia \\ Email address: \\ tadessegebayh1257@gmail.com (T. Gebeyehu), Bayezinabe82@gmail.com (B. Zinabe) \\ ${ }^{*}$ Corresponding author
}

To cite this article:

Tadesse Gebeyehu, Baye Zinabe, Teshager Akalie. Estimation of Concentration of Naturally Occurring Radioactivity and Radiation Hazards, in Iron Ore Deposit Soil from Wag-Himra Zone, Ethiopia. American Journal of Physics and Applications. Vol. 9, No. 2, 2021 , pp. $42-47$. doi: 10.11648/j.ajpa.20210902.13

Received: April 3, 2021; Accepted: May 6, 2021; Published: MM DD, 2021

\begin{abstract}
The current study looked at the concentration of naturally occurring radioactivity and radiation hazards in iron ore deposited in soil. The aim of this study was to identify the dose of radiation which is emitted from rocks, soil and some building materials, the radiation dose and the effect in the area. In this work, analyses of the sample soils were performed with a computer-based gamma-spectrometry system with software of G-2000 for qualitative and quantitative determination of gamma-emitting radionuclide of natural occurrence of radioactive materials. The quantitative investigation of natural radioactive materials of ${ }^{238} \mathrm{U},{ }^{232} \mathrm{Th}$ and ${ }^{40} \mathrm{~K}$ were $11.688 \pm 0.42 \mathrm{~Bq} / \mathrm{kg}, 23.505 \pm 0.925 \mathrm{~Bq} / \mathrm{kg}$ and $141.48 \pm 4.403 \mathrm{~Bq} / \mathrm{kg}$ respectively. In addition to this, the results of absorbed dose rate, annual effective dose equivalent, radium equivalent activity and representative gamma index of the sample were much less as compared to recommended international values by UNSCEAR2000. At low activity concentrations of the radionuclides produce low background radiation to the environment. The value obtained from the experiment reveals that the radiation hazards emitted by natural radionuclides in the soil cause insignificant harm to the public from the Wag-himra iron ore deposit soil. The concentration of natural radioactive elements in this area's soil could be used for construction purposes without causing any significant radiological hazards to humans for the time being.
\end{abstract}

Keywords: Hazard, Radiation, Concentration, Radionuclide, Dose

\section{Introduction}

Naturally occurring radioactive material (NORM) is material containing radioactive elements such as uranium, thorium, and their decay products. About 340 nuclides have been found in nature, of which about 70 are radioactive and are found mainly among the heavy elements. All elements having an atomic number greater than 80 possess radioactive isotopes, and all isotopes of elements heavier than number 83 are radioactive [1]. Virtually all geologic material occurring in nature is radioactive to some degree, and could potentially be categorized as NORM. However, NORM is so ubiquitous that it cannot be practically managed as a radioactive waste; usually, it does not require such management because it is sufficiently dilute or is isolated beneath the surface of the earth. However, in some instances (e.g., particularly high local concentrations of thorium or radium), actions may need to be taken to protect public health [2].

The most naturally occurring radioactive minerals are obtained in ore such as Autunitic (hydrated calcium uranium phosphate), Brannerite (uranium titanate), Carnotite (potassium uranium vanadate), Monazite (a mixed rare earth and thorium phosphate), Thorianite (thorium dioxide) and Uraninite (uranium dioxide). The vast majority of the radioactive content in minerals or ores is either uranium-238 or thorium-232. Many of these minerals may become deposited in both bone and wood fossils [3].

Ethiopia is one of the countries in the world which has mineral deposit areas. These ore/alloy deposit areas may produces naturally occurring radioactive minerals. From these sites, Wag himra/Sekota is one of mineral/ore deposed district place in Ethiopia [7]. Ethiopia is going to extract iron 
ore on large scale for first time, after an agreement was signed by ministry of mines and energy and Sekota mining Plc on August 24, 2017 [4]. The exploring of iron ore about $740 \mathrm{~km}$ north of Addis Ababa in three border weredas; Sekota, Ziquale and Abergelle of Wag himra zone. It covers $242 \mathrm{~km}^{2}$. Based on the above information a researcher had a tendency to understand the presence of naturally occurring radioactive radiation and its effect to the environment from iron ore deposit soil because naturally occurring radioactive materials (NORM) is substances that exist in the earth's crust and the surface with the combination of mineral which deposed on soil [5].

The aim of this study was, to identify the dose of radiation which is emitted from rocks, soil and some building materials, the radiation dose and the effect in the area. The estimation of exposures of humans to the various sources of radiation is important [6]. It is probably the scientific subject that attracts most public attention and arouses controversy. Since radiation of natural origin is responsible for most of the total radiation exposure, knowledge of the dose received from natural sources is very important in the discussion not only of its effects on health but also of the incidence of other radiation from man-made sources [8].

Radioactivity is the spontaneous emission of atoms. Radiation becomes a concern when these particles and energy come in contact with molecules inside the human body, because this interaction can result in cell damage or death [9]. Radioactivity contaminated land can arise as a result of industrial processes, including past waste disposal or accident. Radionuclide could be present on land as a result of a number of past land uses. Contamination of land could occur during the extraction and handling of materials containing high levels of naturally occurring radionuclide materials [10].

In generally, radioactive elements can produce three types of radiation: Alpha, Beta, and Gamma. Alpha rays are the nuclei of helium atoms, two protons and two neutrons bound together. Alpha rays have a net positive charge. Alpha particles have only a weak ability to penetrate [11]. A couple of inches of air or a few sheets of paper can effectively block them. Beta rays are identical to the electrons found in atoms. Beta rays have a net negative charge. Beta rays have a greater penetrating power than Alpha rays and can penetrate $3 \mathrm{~mm}$ of aluminum. Gamma rays are high-energy photons. This type of ray has the greatest penetrating power. It is able to pass through several centimeters of lead and still be detected on the other side. Thick lead is needed to protect against gamma radiation. Radiation can categorize in to two with accordance of their ionizing (i.e. Ionizing and non-ionizing). The ionizing radiation includes alpha particles beta particles and gamma ray and non-ionizing radiation includes which cannot have ionized [12].

Radiation can damage living tissue by changing cell structure and damaging DNA. The amount of damage depends upon the type of radiation, its energy and the total amount of radiation absorbed [13]. Also, some cells are more sensitive to radiation. Because damage is at the cellular level, the effect from small or even moderate exposure may not be noticeable. Most cellular damage is repaired. Some cells, however, may not recover as well as others and could become cancerous. Radiation also can kill cells [14].

According to their existence and effect of NORM the people should aware about the hazard. But in our country Ethiopia no more studied concerning the NORM except a few studies [15]. This study, therefore, was deal about the presence of naturally occurring radioactive minerals radiation in soil of iron ore deposed in Wag himera zone, Ethiopia including the amount of radiation dose and its effects on human body [16].

\section{Material and Methods}

\subsection{Description of the Study Area}

This research article was studied wag-himera ore deposit is found in Amhara region Wag himra zone Sekota wereda, Ziquale wereda and Abergelle wereda border kebelles, Ethiopia. The iron ore deposit soil $2231 \mathrm{~m}$ highs and located between $14^{\circ} 11^{\prime} 17^{\prime}$ 'north longitudes and $38^{\circ} 44^{\prime} 11^{\prime}$ 'east. The geographical description is state bellow.

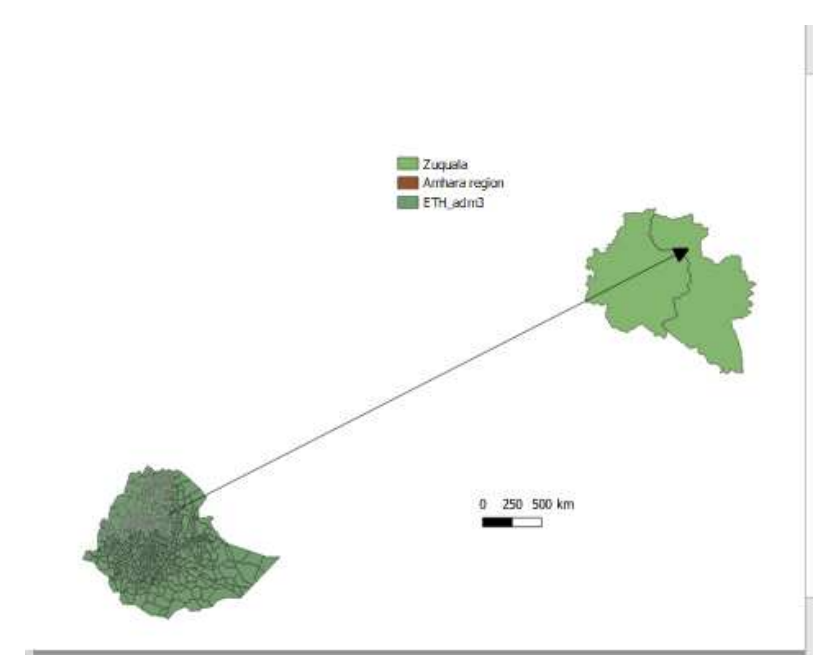

Figure 1. Geographical map of the study area of iron ore deposit soil.

\subsection{Materials}

The study was required all necessary nuclear physics laboratory equipment; HPGe gamma ray spectroscopy, Stainless steel cylindrical sampler, $10 \mathrm{~cm}$ lead layer shield, high power supply and oven, Polyethylene beaker and Mortar and Pestle.

\subsection{Sample Technique and Preparation}

Judgmental sampling was used to select some parts of the iron ore deposit soil in which the researcher believes that naturally occurring radionuclide mineral would be available. The specific places in which we collected the data were only ten due to the broadness of area of the sample site, shortage time and financial constraint. The sample was drawn from the targeted population by using convenience-sampling 
technique. Although, non-probability sampling has problems related to selection bias, in small inquiries and researches by individuals, the sampling technique adopted [17]. Thus, the two non-probability techniques i.e. judgmental and convenience were used to select the sample from the targeted population. Thus, smaller chunks of a unit sample were chosen to represent the relevant attributes of the whole of the units [18]. For the purpose of this study only convenience sampling was considered as a sample frame, because convenience sampling is conducted based on the interest me. First, the iron ore deposit soil area was arranging in to ten clusters based on the information of iron ore soil deposition from the whole area and then each cluster was divided in to four units which are apart from meanly $300 \mathrm{~m}$ in study area. Samples were taken from a depth of $25-30 \mathrm{~cm}$ after removing the possible contamination on the top surface of undisturbed soil [19].

Therefore, from small chunk unit 500g-1000g sample were pack in a plastic container. Soil samplings were collected from ten specific places of iron ore deposit site at Wag-himra zone.

\subsection{Sample Preparation}

The sample of soil was dried in at room temperature for five consecutive days and dried by oven with at temperature of $105^{\circ} \mathrm{C}$ for 24 hours to ensure that moisture is completely remove and until sample had constant weight. From the selected sample of $1 \mathrm{~kg}$ soil, the researcher prepared two samples and each sample was measured $500 \mathrm{~g}$ by digital beam balance. The samples were crush, homogenized, and sieve through a standard $2 \mathrm{~mm}$ mesh size, which is the optimum size enrich in heavy minerals. Weight samples researcher was placed in polyethylene beaker, of $300 \mathrm{~cm}^{3}$ volume each. The beakers were completely sealed for 4 weeks to reach secular equilibrium where the rate of decay of the daughters becomes equal to that of the parent [20]. This step is necessary to ensure that radon gas confined within the volume and the decay products were also remaining in the sample.

\subsection{HPGe Gamma Ray Spectroscopy}

In this work, analyses of the sample soils were performing with a computer-based gamma-spectrometry system with software of G-2000 for qualitative and quantitative determination of gamma-emitting radionuclide of NORM. The High Purity Germanium (HPGe) detector is coupled to a Multi-Channel Analyzer (MCA), and has cooled with liquid nitrogen (cryostat) to temperature of $-196.25^{\circ} \mathrm{C}$ to reduce noise and for good resolution [21]. The detector is mounted in a vacuum chamber which is attached to or inserted into an $\mathrm{LN}_{2}$ Dewar or an electrically powered cooler. The sensitive detector surfaces are thus protected from moisture and condensable contaminants. The relative efficiency of the detector is $70 \%$ with energy resolution of $1.9 \mathrm{keV}$ at gamma ray energy of $1332 \mathrm{keV} \gamma$-emission of cobalt -60 .

The measurement of activity concentrations of the radionuclide of ${ }^{238} \mathrm{U},{ }^{232} \mathrm{Th},{ }^{226} \mathrm{Ra}$ and ${ }^{40} \mathrm{~K}$ in the sample was evaluated by using software associated with the detector of
GENIE- 2000 software, the gamma ray spectra was analyze. In all measurement of radiation, the background radiation outside and inside the detector shielding were measured using an empty marginally beaker [22].

The activity concentrations of the sample were measured under the same manner as background radiation. This background radiation were subtract from measured gamma spectrum of the sample before calculating the activity concentration. The two soil sample each were counted for 10 hours $(36,000 \mathrm{se})$ for two consecutive days to get measurable concentration activity because the amplifier must take a longer time to process the signal and develop its linear pulse, or else not all of the incident energy would reflected in that pulse [23].

More specifically, the ${ }^{232} \mathrm{Th}$ concentration was determined from the average concentration values of ${ }^{228} \mathrm{Ac}$ in the samples. The concentration of ${ }^{238} \mathrm{U}$ was determined from the average concentrations of the ${ }^{214} \mathrm{~Pb}$ and ${ }^{214} \mathrm{Bi}$ decay products, whereas the measurement of ${ }^{40} \mathrm{~K}$ concentration was taken from gamma-ray line of potassium.

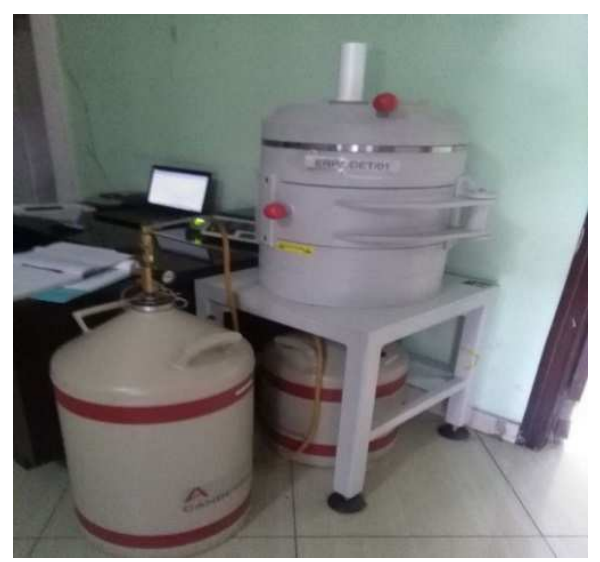

Figure 2. HPGe detector in Ethiopia radiation protection.

\subsection{Energy Calibration}

The efficiency values plotted against energy resulted in an exponential curve. The displayed equation on the absolute efficiency calibration curve was used to calculate the detection efficiency of radionuclide at any energy, E, within the energy range $(0-2500 \mathrm{KeV})$ : Efficiency calibration curve using mixed radionuclides standard, the plot shows that the efficiency of photon detection by the HPGe detector decreases with increasing photon energy. This trend conforms to the expected behavior of HPGe detectors [10].

$$
\varepsilon_{\mathrm{abs}}=\mathrm{a} \times \mathrm{E}^{-\mathrm{b}}+\mathrm{C}
$$

Where: $\mathrm{E}$ is energy of gamma-ray, $\mathrm{a}\left(\mathrm{keV}^{-1}\right)$, and $\mathrm{b}$ are parameters and $\mathrm{C}$ is constant of the sample.

\subsection{Minimum Detectable Activity (MDA)}

The minimum detectable activity (MDA) is defined as the smallest quantity of radioactivity that could be measured under specified conditions; i.e. the minimum concentration 
level of radioactivity that can be determined to be statistically significant from an analytical blank, and includes sample holder and everything else that may be counted with an actual sample; to ensure that there is a $95 \%$ probability of the true net counts. For a low-level counting particularly in environmental level systems, MDA is significant above which counts are statistically significant of the measurement. For this research, only Marnelle beaker filled with selected soil sample and counted for 10 hours $(36,000 \mathrm{se})$ such that the average background peaks were used to determine the MDA. The MDA of ${ }^{238} \mathrm{U}$ was estimated from the average activity concentration of ${ }^{214} \mathrm{~Pb}$ at gamma peaks of $[295.21 \mathrm{keV}$ $(19.20 \%)]$ and ${ }^{214} \mathrm{Bi}[609.31 \mathrm{keV}(46.3 \mathrm{O} \%)] .{ }^{232} \mathrm{Th}$ was estimated from peaks of ${ }^{228} \mathrm{Ac}[911.21 \mathrm{kev}(26.6 \%)]$. Finally, ${ }^{40} \mathrm{~K}$ photo peak energy $1460.83 \mathrm{keV}(10.67 \%)$ was used for computing its MDA. The minimum detectable activity depends on the gamma emission probability $\left(\mathrm{P}_{\gamma}\right)$ and absolute efficiency $\left(\varepsilon_{\mathrm{f}}\right)$ of the detector. The mathematical expression of MDA is given by the following equation

$$
\mathrm{MDA}=\frac{1.645 \sqrt{\mathrm{NB}}}{\varepsilon \mathrm{fp} \gamma \mathrm{TCm}}
$$

Where,

$\mathrm{N}_{\mathrm{B}}$ is the background counts in the region of interest for a particular radionuclide,

$\varepsilon f$ is the photo peak efficiency,

$\mathrm{P}_{\gamma}$ is gamma emission probability,

TC is the counting time and

$m$ is the weight of the sample container. The unit of MDA is Becquerel per kilogram $(\mathrm{Bq} / \mathrm{kg})$.

\subsection{Data Analysis}

The major objective of this study was an estimation of naturally occurring radionuclide mineral concentration and radiation in soil sample of Wag-himra iron ore deposit area. In order to achieve/evaluated those mentioned objective of the study, a different technique has been applied. For instance, soil samples were sealed 4 week in plastic beaker and finally by using high pure germanium (HPGe) detector the concentration of NORM were analyzed /specified as follow.

\subsection{Calculation of Concentrations}

The specific activity concentration of radionuclide (primordial) was determined based on the following formula;

$$
\mathrm{A}_{\mathrm{E}}=\frac{\mathrm{N}}{\varepsilon * \mathrm{t} * \gamma * \mathrm{~m}}
$$

Where; $\mathrm{N}$ is the Net Peak Area of a peak at energy $\mathrm{E}, \varepsilon$ is the detection efficiency at energy $\mathrm{E}, \mathrm{t}$ is the counting live time, $\gamma$ is the number of gammas per disintegration of this nuclide for a transition at energy $\mathrm{E}$, and $\mathrm{m}$ is the mass in $\mathrm{kg}$ of the measured sample.

All values of $N, E, t, \gamma$ and $\eta$ are produced from the sample by using HPGe detector. More specifically, the corresponding activity concentration for ${ }^{232} \mathrm{Th}$ was calculated making use of the energy transitions $911.21 \mathrm{keV}(26.60 \%)$ and $968.97 \mathrm{keV}$ $(16.20 \%)$ of ${ }^{228} \mathrm{Ac}$. The activity concentration for ${ }^{40} \mathrm{~K}$ was determined from the emission at $1460.81 \mathrm{keV}(10.67 \%)$ of gamma-ray line, and the corresponding activity concentration for ${ }^{238} \mathrm{U}$ or ${ }^{226} \mathrm{Ra}$ was calculated average transition with energies $609.31 \mathrm{keV}(46.30 \%), 1120.29 \mathrm{kev}(15.10 \%)$ and $1764.49 \mathrm{keV}(15.80 \%)$ of ${ }^{214} \mathrm{Bi}$, and $295.21 \mathrm{kev}(19.20 \%)$ and $351.92 \mathrm{kev}(37.20 \%)$ of ${ }^{214} \mathrm{~Pb}$.

\section{Result and Discussion}

\subsection{Soil Sample Activity Concentration}

Composite soil samples prepared from iron ore deposit area of wag-himra zone, Ethiopia. The samples were collected ten clusters (places) from different locations across wag-himra iron ore deposit soil.

Table 1. The concentration of naturally occurring radionuclide minerals from soil sample (Bq/kg).

\begin{tabular}{llll}
\hline \multirow{2}{*}{ Sample code } & \multicolumn{2}{l}{ Activity concentration in soil $(\mathbf{B q} / \mathbf{k g})$ sample } & K-40 \\
\cline { 2 - 4 } & $\mathbf{U - 2 3 8}$ & $\mathbf{T h - 3 2}$ & $141.48 \pm 4.40336$ \\
\hline SS1 & $11.688 \pm 0.417$ & $23.50521 \pm 0.92525$ & $141.48 \pm 4.4033$ \\
SS2 & $11.688 \pm 0.471$ & $23.502 \pm 0.92525$ & $141.48 \pm 4.4033$ \\
mean+er & $11.688 \pm 0.471$ & $23.5052 \pm 0.92525$ & 420 \\
worldwide average & 33 & 45 & $140-850$ \\
worldwide range & $16-110$ & $11-64$ & Less \\
\hline
\end{tabular}

From Table 1 it shows clearly the value of activity concentration of the same sample is not varying with a few days when the researcher used the same instrument with the same time limit but after a number of days the value may change because of half-life of radionuclide.

From the calculated value activity concentration for ${ }^{238} \mathrm{U}$ was at least three times less than the worldwide mean activity concentrations reported by UNSCEAR-2000. The activity concentration of ${ }^{40} \mathrm{~K}$ was higher than minimum worldwide range but not maximum limited value reported by UNSCEAR-2000. However, the activity concentration of
${ }^{232} \mathrm{Th}$ was high as compare as with other radionuclide of those soil but lower than the worldwide average value reported by UNSCEAR-2000. According to UNSCEAR2000 report, all soils contains trace amount of terrestrial radionuclides as compared as rocks, therefore, the soil collected from wag-himra iron ore deposit area may contains trace amounts of radioactive ${ }^{238} \mathrm{U}$ decay series, ${ }^{232} \mathrm{Th}$ decay series and ${ }^{40} \mathrm{~K}$. Likewise, the soil samples were collected from iron ore deposit soil. Then the most studied publish journal reveals that the radionuclides activity concentration in raw material of iron and soil were trace level. So the result 
found in sample is quite enough.

Table 2. Absorbed dose and annual effective dose.

\begin{tabular}{llll}
\hline Radionuclide & external $\boldsymbol{\gamma}$-dose in soil $(\mathbf{n G y} / \mathbf{h})$ & AEDS out door in soil $(\mathbf{m S v} / \mathbf{y})$ & AEDS indoor in soil (mSv/y) \\
\hline U-238 & 5.39985 & 0.0066223 & 0.02649 \\
Th-232 & 14.197 & 0.017411 & 0.069645 \\
K-40 & 6.64956 & 0.00815 & 0.03262 \\
Sum & 26.24644 & 0.0321833 & 0.128755 \\
Mean & 8.748812 & 0.010727767 & 0.042918333 \\
Worldwide average & 60 & 0.07 & $0.41(0.39)$ \\
World wide range & $18-93$ & $0.3-0.6$ & $0.3-0.6$ \\
\hline
\end{tabular}

\subsection{Comparison with Other Areas of the Activity Concentration}

The result of the activity concentration found from soil sample of Wag-himra iron ore deposit was compared and contrasted with worldwide activity concentration. This naturally occurring radionuclide in soil was almost very small except a few region/country. The most of activity concentration of the terrestrial radionuclide around the world are higher than theses soil samples' mean activity concentration. For instance the calculated average activity concentration found for ${ }^{238} \mathrm{U}$ was completely small over all worldwide.

Based on table 2 both absorbed dose rate and annual effective dose calculation of the soil sample from wag-himra iron ore deposit were much less than that of permissible limit recommended by UNSCEAR-2000, and IAEA-2003. Thus, the amount terrestrial radionuclides in the studied area might very small comparing with other areas mean value concentration.

\subsection{Result of Gamma Radiation Level Index and Excess Lifetime Cancer Risk (ELCR)}

The composite samples prepared from the ten soil samples collected from the wag-himra iron ore deposit area were assigned with the sample codes SS1 and SS2 but the result of the two were the same. Table 2 shows a summary of the results obtained for analysis of these samples. ICRP-2007. From the assessment soil sample of iron ore deposit area in Wag-himra an internal hazard index value.

\section{Conclusion}

This work considered the estimation of the level of NORMs and associated radiological hazards and risks of iron ore deposited area in Wag-himra, Ethiopia. This study NORM was analysis from sample of soil from at mineral/iron ore deposit area. The NORMs identified in the samples were ${ }^{238} \mathrm{U},{ }^{232} \mathrm{Th}$ and ${ }^{40} \mathrm{~K}$. The corresponding value of activity concentration for ${ }^{238} \mathrm{U},{ }^{232} \mathrm{Th}$ and ${ }^{40} \mathrm{~K}$ were estimated to $11.688 \pm 0.417 \mathrm{~Bq} / \mathrm{kg}$, $23.505 \pm 0.92525 \mathrm{~Bq} / \mathrm{kgand} 141.48 \pm 4.4033 \mathrm{~Bq} / \mathrm{kg}$ with having same values for both sample, respectively. In comparison with the worldwide average value reported by UNSCEAR-2000, the values of $238 \mathrm{U}, 232 \mathrm{Th}$ and $40 \mathrm{~K}$ were less than the recommended average values of $33 \mathrm{~Bq} / \mathrm{kg}, 45 \mathrm{~Bq} / \mathrm{kg}$ and 420 $\mathrm{Bq} / \mathrm{kg}$, respectively. Thus, this implies that the NORMs activity concentration at Wag-himra iron ore deposited area is low respect to the concentrations of the nuclides with other region/country. These low activity concentrations of the radionuclides were produce low background radiation to the environment. The average absorbed doses rates of the study area of ${ }^{238} \mathrm{U},{ }^{232} \mathrm{Th}$ and ${ }^{40} \mathrm{~K}$ were estimated to $8.788 \mathrm{nGy} / \mathrm{h}$, which is less than $60 \mathrm{nGy} / \mathrm{h}$ recommended by UNSCEAR2000. Correspondingly, the annual effective dose of the study area was estimated to $0.03218 \mathrm{mSv} / \mathrm{y}$. Which was smaller than the half of world mean average value i.e. $0.035 \mathrm{mSv} / \mathrm{y}$ and mean value reported by UNSCEAR-2000 is $0.07 \mathrm{mSv} / \mathrm{y}$. Therefore, the soil from the study area can be used for construction purposes without causing any significant radiological hazards to humans for the time being. In generally, the study area is enriching with mineral. So the risk factor and significant harm of activity concentration may increase through long live and due to extraction if it is performed.

\section{Recommendation}

We have suggested for further study there should be more sample preparation including rocks and water by using sophisticated machines which can collect within range of depth of location of iron ore to get measurable activity concentration and to understand the radiological hazard of NORM to the people who dwell there. The mineral content of soil and rocks should be studied in detail because it is important to assess radiation dose and the quest for understanding the origin of rocks of different types. If iron ore is extracted, it will provide a benefit for society and the country by keeping rules and regulations of radioactive waste management. We recommended that the concerned body should give attention to the area.

\section{Acknowledgements}

First, we would like to thank Almighty God for giving me an opportunity that we have received Study. Next, we would like to express my deepest gratitude to physics department staff's expert guidance, constructive comments, suggestions and encouragement without which this work could not have been completed.

\section{Conflicts of Interest}

The authors no conflict interest. 


\section{References}

[1] Ayham Assie and et al (2016). Determination of natural radioactivity by gamma spectroscopy in Balad soil, Iraq. Advances in Applied Science Research, 7 (1): 35-41.

[2] Belete Derib (2017). Evaluation, Characterization and management of Naturally Occurring Radioactive Materials and disused radioactive waste in Water and Soil Samples. Master's Thesis, Addis Ababa University, Institute of Technology, pp. 20-29.

[3] Beretka and P. J. Mathew (1985). Natural Radioactivity of Australian building materials. Health Phys, 48: 87-95.

[4] Birhanu W. Tsegaye (2015). Elemental analysis of geological, herbal and food samples using instrumental neutron activation analysis (INAA). Submitted in partial fulfillment of the requirements for the degree of doctor of philosophy in physics. At college of natural science, department of physics, Addis Ababa university, Ethiopia, pp. 37-39.

[5] Edward L. Alpen (1998). Radiation Biophysics. Second edition, Academic press, USA, pp. 1-35

[6] ERP (2012). United state Environmental radiation protection agency. pp. 8 .

[7] Faanu A. (2011). Assessment of public exposure to naturally occurring radioactive materials from mining and mineral processing activities of tarkwa goldmine in Ghana. In partial fulfillment of the requirements for the degree of doctor of philosophy in chemistry. Kwame Nkrumah university of science and technology, Kumasi, Ghana, pp. 51.

[8] Glenn F. Knoll (2008). Radiation Detection and Measurement. Third edition, John Wiley \& Sons, Inc. New York/Chichester/, pp. 57-67.

[9] Gordon R. Gilmore (2008). Practical Gamma ray Spectrometry. $2^{\text {nd }}$ edition, John Wiley \& Sons Ltd, Warrington, UK, PP. 56-80.

[10] Herman Cember and Thoma. E. Johnson (2009). Introduction to Health physics. $4^{\text {th }}$ edition, the McGraw-Hill Company, pp. $135-240$.

[11] http://www.epa.gov/rpdweb00/ understand/equilibrium. Html.
[12] https://hornaffairs.com/2017/08/28/sekota-mining-extractiron-wag-himra-zone/amp/.

[13] IAEA (2008). Naturally occurring radioactive material (NORM V). Printed by the IAEA in Austria, pp. 31.

[14] ICRP (2000). International Commission on Radiological Protection. protection of the Public in Situations of Prolonged Radiation Exposure, Publication 82, Elsevier Science, Oxford.

[15] Janet A. Ademola (2014). Estimation of Annual Effective Dose Due to Ingestion of Natural Radio nuclides in Cattle in Tin Mining Area of Jos Plateau, Nigeria. Natural Science, 6: 255-261.

[16] Merril Eisenbud and Thomas Gesell (1997). Environmental Radioactivity. Fourth edition, Academic press, USA, pp. 135180 .

[17] Podgorsak (2006). Radiation physics for medical physicist. $1^{\text {st }}$ edition. Printed in Germany, pp. 263.

[18] Ranjit Kumer (2011). Research Methodology step-by-step guide for beginner. Third edition, SAGE Publications Ltd, pp. 186.

[19] Sami Alharbi (2016). Measurement and monitoring of naturally occurring radioactive materials for regulation. Submitted to the Science and Engineering Faculty, Queensland University of Technology, in fulfillment of the degree of Doctor of Philosophy in Radiology Queensland university, pp. 9-23.

[20] Teklemariam Tessema (2015). Elemental Concentration and Natural Radioactivity Studies Some Biological and Geological Samples Taken from Selected Zone of Ethiopia by the Method of Instrumental Neutron Activation Analysis (INAA). PhD Thesis, Addis abebe University, pp. 90-92.

[21] UNSCEAR (1988). Sources, effects and risks of ionizing radiation. UNSCEAR Report to the General Assembly.

[22] UNSCEAR (2000). Sources and effects of ionizing radiation. UNSCEAR Report to the General Assembly, with Scientific Annexes, UN, New York, 1: 19-87.

[23] UNSCEAR (2016). Sources, effects and risks of ionizing radiation. UNSCEAR Report to the General Assembly, with Scientific Annexes, UN, New York, pp. 19-54. 